УДК -004.62

\title{
SYSTEM OF SPECIALIZED SEARCH AND SELECTION OF MARKETING DATA FROM THE INTERNET
}

\author{
T. Dzhurenko, E. Myakshylo, V. Romanenko \\ National University of Food Technologies
}

\begin{tabular}{|c|c|}
\hline Key words: & ABSTRACT \\
\hline $\begin{array}{l}\text { Semantic search } \\
\text { Searching system } \\
\text { Request } \\
\text { Relevant document } \\
\text { Set of documents } \\
\text { Parser }\end{array}$ & $\begin{array}{l}\text { The issue of searching text data in the Internet is analyzed in } \\
\text { this article. The analysis revealed that the existing mathe- } \\
\text { matical tools and software are insufficient for meeting the } \\
\text { challenges associated with the processing of multiple re- } \\
\text { sources generated by popular search engines. To improve } \\
\text { the efficiency of marketing data selection in a plurality of }\end{array}$ \\
\hline $\begin{array}{l}\quad \text { Article history: } \\
\text { Received 14.05.2017 } \\
\text { Received in revised form } \\
05.06 .2017\end{array}$ & $\begin{array}{l}\text { documents found on the Internet, it was proposed to use the } \\
\text { specialized information system, which provides for the for- } \\
\text { mation of a single text document relevant to the user by } \\
\text { analyzing text data. }\end{array}$ \\
\hline
\end{tabular}

Accepted 24.06.2017

Corresponding author:

T. Dzhurenko

E-mail:

tania-dzhurenko@mail.ru

DOI: $10.24263 / 2225-2924-2017-23-4-4$

\section{СИСТЕМА СПЕЦІАЛІЗОВАНОГО ПОШУКУ І ВІДБОРУ МАРКЕТИНГОВИХ ДАНИХ 3 МЕРЕЖІ IHТЕРНЕТ}

\author{
Т.С. Джуренко, О.М. М'якшило, В.М. Романенко
}

Національний університет харчових технологій

У статті визначено проблеми пошуку текстових даних у мережі Інтернет. У результаті аналізу виявлено, що наявне математичне та програмне забезпечення недостатне для розв'язання задач, пов'язаних з обробкою множинних ресурсів, які утворюються в результаті роботи популярних пошукових машин. Для підвищення ефективності відбору маркетингових даних у множині документів, знайдених у мережі Інтернет, було запропоновано інформаційну систему спеціалізованого пошуку, яка за рахунок аналізу текстових даних забезпечує формування єдиного, релевантного запиту користувача текстового документа.

Ключові слова: семантичний пошук, пошукова система, запит, релевантний документ, множина документів, парсер.

Постановка проблеми. Інформація, яка використовується в маркетингових дослідженнях, - це сукупність відомостей, повідомлень про господарську (комерційну) діяльність підприємств та їх зовнішнє середовище. 
Існує два види даних, які покладені в основу маркетингових досліджень і обумовлюють складання їх плану:

- первинні дані - інформація, яку збирають уперше для досягнення конкретної мети певного дослідження (польові дослідження);

- вторинні дані - інформація, яка вже була зібрана раніше для іншої мети (кабінетні дослідження).

Основними джерелами вторинних даних, поряд з традиційними, є:

- внутрішні дані про діяльність підприємства, доступ і аналіз яких забезпечується корпоративними або спеціалізованими інформаційними системами;

- дані, доступні через Інтернет. У цьому випадку джерелами можуть виступати web-сторінки i web-сайти підприємств конкурентів, бази даних, телеконференції та файлові сервери.

Пошук маркетингових даних у мережі Інтернет має свою специфіку, як i пошук будь-якої професійно-орієнтованої інформації. Запити користувачамаркетолога обмежені словником професійних термінів і виразів, що піддаються класифікації і можуть бути представлені у вигляді онтології [1, Р. 508-520].

Множина документів знайдених будь-якою пошуковою системою у мережі Інтернет за запитом користувача містить набір документів різних форматів і розмірів. Для отримання довідки стосовно питання, що нас цікавить, слід відкрити десяток, або більше документів, які ще слід опанувати, щоб вибрати необхідну інформацію. Сучасні пошукові системи використовують багато методів, щоб зробити пошук найбільш ефективним, але цього недостатньо. Користувачеві бажано мати єдиний документ, який містить конгломерат знайдених даних, оцінених за релевантністю. У пропонованій статті зроблено спробу створення інформаційної системи спеціалізованого пошуку, яка дає змогу отримати єдиний документ зі знайдених у мережі Інтернет за запитом користувача-маркетолога.

Аналіз останніх досліджень і публікацій. Завдання пошуку даних в умовах швидкого розвитку сучасних інформаційних технологій займає одне 3 центральних місць у сучасній теорії інформації і має фундаментальне значення в процесах обробки цифрових даних. Пошук - найпростіший спосіб доступу до текстової інформації. Сучасні пошукові машини мають такі можливості [2]:

- індексування тесту;

- пошук за ключовими словами;

- морфологічний пошук;

- логічна мова запитів;

- ранжування документів відповідно до ключового запиту.

Однак при сьогоднішніх швидкостях зростання обсягів інформації в мережі Інтернет цих можливостей стає недостатньо. Взагалі видів пошуку дуже багато і вони розрізняються між собою способом обробки даних. Але у кожному алгоритмі пошуку є свої переваги і недоліки.

Статичні і семантичні методи пошуку, відповідно до форми подання інформації (графи, векторно-просторова модель, латентно-семантичне індексування), запропонували Дж. Солтон, С. Думайс, Е. Расмусен та інші [3, С. 235234]. Загальним недоліком цих методів $є$ недостатня точність порівняння 
документів зі змістом запиту, яка необхідна в автоматизованих системах інформаційного пошуку.

Одним із способів підвищення точності $є$ використання так званої функції «знайти щось схоже». Користувачу потрібно уточнити введений запит, а система в той же час виділить один або декілька знайдених документів $\mathrm{i}$ виокремить подібні до зразка.

«Схожість» можна досягнути використанням у пошуковій системі онтології - множини понять, пов'язаних семантичними зв'язками та визначеними для них функціями. На сьогодні розроблено низку таких методів (Д.П. Ночевнов, Г. Бульсков, ін.) [4, С. 105-111], проте в них онтологія є статичною, вагові коефіцієнти понять і зв'язки між ними призначаються вручну, що ускладнює їх ефективну реалізацію в автоматизованих системах [5, С. 51—54].

Якісними показниками, що впливають на роботу пошукової системи, $\epsilon$ такі:

- наявність розширеного пошуку;

- наявність спеціалізованого пошуку;

- повнота пошуку;

- релевантність пошуку;

- доступні індивідуальні налаштування;

- зручність інтерфейсу і простота використання [6, С. 200-201].

Проте жодна 3 пошукових систем не відповідає повністю висунутим вимогам до роботи 3 даними інформаційно-аналітичної системи підтримки прийняття рішень промислового підприємства, тому завдання полягає в тому, щоб розробити ефективну систему спеціалізованого пошуку даних, орієнтовану на ідентифіковані запити користувачів у професійному інформаційному середовищі. Йдеться про пошук маркетингових даних для харчового підприємства.

Метою дослідження $є$ аналіз пошукових систем і методів пошуку інформації в мережі Інтернет і розробка інформаційної технології відбору релевантних маркетингових даних, серед знайдених у глобальній мережі, за запитом користувача.

Викладення основних результатів дослідження. Організація відбору релевантних даних серед знайдених в мережі Інтернет за запитом користувача.

При розробці системи пошуку та відбору маркетингових даних 3 мережі Інтернет використовувався булевий метод пошуку. Булевий пошук - це комбінація елементів, що дозволяють включати і виключати із пошукових результатів документи, що містять певні слова. Це досягається за допомогою булевих операторів and, not, or, near. Популярність цієї моделі пошуку пов'язана передусім 3 простотою іiі реалізації, що дає змогу індексувати i виконувати пошук у великих документальних масивах.

Ті документи, що задовольняють булевий запит, потрапляють у список по черзі. Ідея розширеного булевого пошуку полягає у створенні можливостей для визначення ступеня відповідності документів пошуковому запитові. Це досягається присвоєнням ваги пошуковим термінам. Вага термінів враховується при побудові списку відповідності документів до інформаційного запиту [7, С. 202-209]. 
Пошук і відбір маркетингових даних булевим методом підвищує партинентність результатів пошуку — повноту й точність.

Також використовувався семантичний метод пошуку, який, у свою чергу, оперує всім змістом документа і після цього формується оцінка його релевантності. Інформаційна база зберігається в тезаурусах — різновид словників, у яких вказані семантичні відношення (наприклад, синоніми, антоніми, пароніми, гіпоніми, гіпероніми) між лексичними одиницями. Таким чином, тезауруси слугують інструментом для опису окремих предметних областей.

Ефективним засобом реалізації семантичного пошуку є онтологія, яка описує семантику наявних у мережі тематичних ресурсів. Онтологія ж $\epsilon$ системою, що складається з набору понять і тверджень про ці поняття. Використання онтології у даній системі дасть змогу сформувати та розширити запит користувача за допомогою перетворення його в сполучений логічними зв'язками набір термінів і понять. Запит буде розширюватись шляхом додавання синонімів.

Система спеціалізованого пошуку і відбору маркетингових даних з мережі Інтернет. Авторами запропонована система спеціалізованого пошуку і відбору маркетингових даних $з$ мережі Інтернет для підтримки прийняття рішень маркетологом підприємства, яка:

- здійснює пошук підприємств, що випускають аналогічний асортимент а також успішних конкурентів, чия продукція користується попитом;

- здійснює вибір зображень, що дають користувачеві вичерпну інформацію про продукцію;

- дає змогу переглянути альтернативну продукцію підприємств-конкурентів.

Розглянемо алгоритм пошуку та відбору знайдених у мережі Інтернет маркетингових даних:

1. Користувач вводить запит у поле введення Системи пошуку маркетингових даних (рис. 1).

Введіть назву підприємства

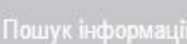

Рис. 1. Введення запиту у системі пошуку маркетингових даних

2. Запит надходить у змінну zаріt i заноситься до БД. У рамках булевої моделі запити і документи подаються у вигляді термів - ключових слів $\mathrm{i}$ стійких словосполучень. Зображенням запиту є множина пар певних елементів пошуку та їхніх значень:

$$
D_{k}=\left\{\left(N_{j k}, V_{j k}\right)\right\}
$$

де $N_{j}$ - ім'я $j$-го елемента даних в описі користувацького запиту; $V_{j}-$ значення цього елемента даних. 
Кожен терм представляється як булева змінна: 0 (терм із запиту, не наявний у документі) або 1 (терм із запиту, наявний у документі). Документи, що необхідно знайти - певна підмножина слів, що, по суті, і $€$ набором терм:

$$
D \in T, D \in\{0,1\}^{n} .
$$

3. Змінна передається на сторінку google.com.ua через посилання, наприклад [8].

4. Запит користувача - це набір ключових слів із булевими зв'язками, наприклад:

$$
\begin{gathered}
t_{1} \text { OR } t_{2} ; \\
t_{1} \text { AND } t_{2},
\end{gathered}
$$

де $t_{1}$ - ім'я файла, який необхідно знайти, $t_{2}$ - заголовок сторінки. За допомогою пошукової системи та операції конкатенації символьних рядків за тематичним запитом $D_{k}$ отримаємо множину $S P$ Веб-сторінок, представлених своїми $H T M L$-кодами:

$$
S P(Q S, P)=\left\{H P_{i}\right\}_{i=1}^{P},
$$

де $P$ - потужність множини $S P$; $H P_{i}$ - елемент множини, що визначає $H T M L$-код $i$ - тої сторінки.

За внесеним запитом користувача отримуємо кортеж документів такого виду:

$$
z_{i}=\left\{\sum d_{i}\right\}
$$

де документи відбираються таким чином:

$$
\begin{gathered}
d_{i}=t(\mathrm{Z}) \in d_{i} \wedge(w(t) \rightarrow \max )=\ll \text { Істина» } ; \\
t(Z)-\text { терм запиту; } \\
w(t)-\text { вага терма. }
\end{gathered}
$$

Більш релевантними будуть ті документи, в яких сукупна вага знайдених термів буде максимальною.

При цьому вага самого терма визначається як добуток функції від кількості входжень терма в документ та функції від величини оберненої кількості документів колекції, в яких зустрічається цей терм:

$$
N t^{*} I D t
$$

де $N t$ - кількість входжень терма в документ; $I D t-$ рідкість терма в колекції.

Пошуковою системою (google) генерується Web сторінка зі знайденими посиланнями, наприклад, результат пошуку за запитом Житомирський+маслозавод.

5. Посилання зберігаємо в базі даних у таблиці «Посилання» і передаємо в програму парсер як зміну URL. 
6. Парсер підключається до сторінки і вилучає з неї посилання за умовою: if (tag.Attributes[«url»] != null \&\& tag.Attributes[«content»] != null \&\& tag.Attributes[«name»].Value.ToLower( $)==$ «description»).

Тобто для кожного документа парсер вибирає url, content, name.

7. Вибрані дані заносяться до БД і через запит «SELECT 'url' FROM 'Посилання' WHERE id_url = temp.url.nomer;» вибираються для подальшої обробки їх парсером.

Temp.url.nomer - тимчасова змінна, що використовується для порівняння i відбору посилань, які відповідають умові.

8. URL знову передається парсеру і він переходить на сторінку, де шукає блоки $<$ content $>$ та $<$ body $>$.

9. Дані вилучаються зі сторінки і вносяться у БД в таблицю «Оброблений документ».

10. Потім відбувається вилучення і видалення всіх HTML кодів сторінки за допомогою функції DeleteKOD.

11. Насамкінець відформатований документ заноситься в таблицю «Форматований документ».

Існує багато способів оцінити документи, знайдені інформаційно-пошуковою системою, на відповідність запиту. На жаль, поняття ступеня відповідності запиту, або іншими словами релевантності, є суб'єктивним поняттям. Таким чином, ступінь відповідності залежить від конкретної людини, що оцінює результати виконання запиту.

Результат пошуку даних у мережі Internet за запитом користувача зображено на рис. 2.

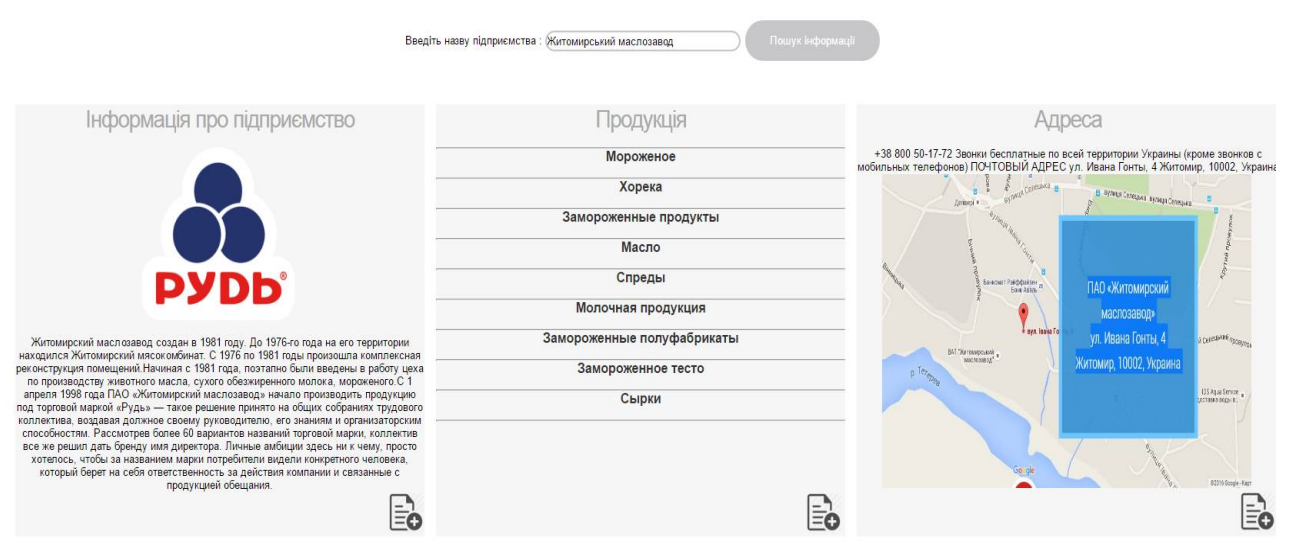

Рис. 2. Результат роботи парсера при запиті «Житомирський+маслозавод»

\section{Висновок}

Актуальність дослідження $є$ очевидною, оскільки життя сучасного суспільства вирізняється динамічністю. Кожен 3 нас у найкоротший термін намагається віднайти корисну, цінну інформацію, що неминуче призводить до зростання популярності Інтернет-служб, які дають змогу просто, швидко, ефективно та якісно надавати різні послуги. 
Наявність великої кількості інформації в мережі Інтернет ускладнює ефективний пошук та аналіз даних, а запропоновані у статті методи дають змогу отримувати точніші результати пошуку шляхом запровадження в системі інтелектуальної компоненти, що здійснює вторинний аналіз результатів пошуку, зручне подання відфільтрованих результатів.

На основі проведеного дослідження, було запропоновано алгоритм пошуку і подальшої обробки web-документів за сформованим запитом користувача. На основі запропонованого алгоритму реалізовано програмний продукт, що обробляє набори сайтів мережі Інтернет на прикладі пошуку маркетингових даних.

\section{Лiтература}

1. Dzhurenko T. Analysis of Text Mining methods in Web search / T. Dzhurenko, O. Myakshylo, G. Cherednichenko // Ukrainian Food Journal. — 2015. — Vol. IV, Iss. 3. - P. 508 - 519.

2. Ашманов И. Информация и знания: невидимая грань [Електронний ресурс]. Режим доступу : http://it2b.ru/blog/arhiv.

3. Даревич P.P. Метод автоматичного визначення інформаційної ваги понять в онтології бази знань / Р.Р. Даревич, Д.Г. Досин, В.В. Литвин // Искусственный интеллект. 2009. — № 3. - С. 343-349.

4. Ночевнов Д.П. Системный анализ методов адаптации информационного поиска в информационно-поисковых системах / Д.П. Ночевнов // Вестник Черкасского государственного технологического университета. - Черкасы, 2006. - Т. 1. - С. 202.

5. Войтко B.B. Порівняльний аналіз пошукових систем як сервісів сучасного документообігу наукових та навчальних організацій / Д.В. Мельник, С.А. Яремко // Вісник Хмельницького національного університету. - 2013. — № 4. - С. 202-207.

6. Шарапов Р.В. Пути расширения булевой модели поиска / Р.В. Шарапов, Е.В. Шарапова // Современные наукоемкие технологии. - 2011. — № 3. - С. $47-49$.

7. Житомирський маслозавод [Електронний ресурс]. — Режим доступу : https://www.google.com.ua/search?q=Житомирський+маслозавод. 